\title{
Species delimitation and sex associations in the bee genus Thygater, with the aid of molecular data, and the description of a new species
}

\author{
Felipe Vieira Freitas ${ }^{1,2}$, José Eustáquio SANTOS JÚNIOR ${ }^{1,3}$, Fabrício Rodrigues SANTOS ${ }^{3}$, \\ Fernando A. SILVEIRA ${ }^{1}$

\begin{abstract}
${ }^{1}$ Departamento de Zoologia, Laboratório de Sistemática de Insetos, Pós-graduação em Zoologia, Instituto de Ciências Biológicas, Universidade Federal de Minas Gerais, Caixa Postal 486, Belo Horizonte, MG 30123-970, Brazil Ribeirão Preto, Universidade de São Paulo, Av. Bandeirantes, 3900, Ribeirão Preto, SP 14040-901, Brazil ${ }^{3}$ Laboratório de Biodiversidade e Evolução Molecular, Pós-graduação em Genética, Departamento de Biologia Geral, Instituto de Ciências Biológicas, Universidade Federal de Minas Gerais, Caixa Postal 486, Belo Horizonte, MG 30123-
\end{abstract} \\ ${ }^{2}$ Departamento de Biologia; Laboratório de Biologia Comparada e Abelhas; Faculdade de Filosofia, Ciências e Letras de \\ 970, Brazil
}

Received 9 October 2017 - Revised 5 February 2018 - Accepted 20 March 2018

\begin{abstract}
Thygater Holmberg 1884, a Neotropical bee genus included in the tribe Eucerini, is distributed from Argentina to Mexico, was last revised almost 50 years ago, and included 30 species. Significant problems in Thygater taxonomy are like those found in other bee taxa: sexual dimorphism (sometimes accentuated); large intraspecific variation in some taxa, especially in color patterns; great similarity among putative recently-diverging species; and scarcity of specimens for study of several apparently rare species. These problems hinder the correct delimitation of species boundaries and could result in an underestimated number of species and incorrect association of sexes. In this taxonomic and phylogenetic study of the genus, morphological and molecular evidence are considered together to elucidate the taxonomy of several Brazilian species of Thygater. The analyses allowed the description of two new species (one already described and other described here), additional support for the synonyms proposed elsewhere and sex associations for several species.
\end{abstract}

Apoidea/sexualdimorphism/Eucerini/Neotropics/new synonym/reciprocalmonophyly/species delimitation

\section{INTRODUCTION}

The Neotropical bee genus Thygater Holmberg (1884), a member of the tribe Eucerini, includes 30 species distributed from Argentina to Mexico, but absent in Chile and the Antilles (Michener 2007; Urban et al. 2012). Some of its

Electronic supplementary material The online version of this article (https://doi.org/10.1007/s13592-018-0576-0) contains supplementary material, which is available to authorized users.

Corresponding author: F. Freitas,

felipevieirafreitas@gmail.com

Manuscript editor: Marina Meixner species, such as Thygater analis (Lepeletier 1841), are relatively common throughout their geographic ranges (Urban 1967). Others, however, are relatively rare, and some are narrowly geographically and environmentally restricted (Urban 1967, 1999; Freitas and Silveira 2017).

The main problems found when working on Thygater taxonomy are the sexual dimorphism (sometimes very accentuated); the large intraspecific variation in some species, especially in color patterns; the great similarity among putative recently-diverging species; and the scarcity of specimens for study of several rare species. These problems, which hinder the correct delimitation of species boundaries (including association of 
sexes), are not exclusive of Thygater. In fact, molecular studies are showing that the number of recognized species is underestimated due to such problems, especially among invertebrates, including bees (e.g., Duda Jr. et al. 2008; Fontaneto et al. 2009; Gibbs 2009a; Koch 2010; Soldati et al. 2014; Wolinska et al. 2009). In dealing with such problems, the association of molecular and morphological characters has proven to be of help in Hymenoptera, including several groups of bees (e.g., Gibbs 2009a, b; Hurtado-Burillo et al. 2017; Nemésio et al. 2013; Pilgrim et al. 2008; Rehan and Sheffield 2011; Santos Júnior et al. 2015; Sheffield et al. 2009). This approach, however, has never been applied to Thygater.

As part of a comprehensive study on the phylogeny and taxonomy of Thygater and related genera, the principles of integrative taxonomy, with the combined use of molecular and morphological data (Dayrat 2005; Padial et al. 2010; Schlick-Steiner et al. 2010; Will et al. 2005), were employed here to test previous sex associations, to search for unknown sexes of species described previously on the basis of a single sex, and to test the boundaries of species of Thygater previously described on the basis of morphological characters alone, especially of those occurring in Brazil, always under a phylogenetic perspective.

\section{MATERIAL AND METHOD}

A total of 356 specimens of Thygater were examined for this study. Specimens employed in molecular analyses are listed in Table I; type specimens of Thygater carijo sp. n. are listed in the species description, in Section 3.3; other specimens studied are listed in Freitas and Silveira (2017). The studied material belongs to the following collections: Centro de Coleções Taxonômicas da Universidade Federal de Minas Gerais (UFMG); Museu Regional de Entomologia da Universidade Federal de Viçosa (UFV); Coleção Entomológica Prof. J. M. F. Camargo of the Universidade de São Paulo, Ribeirão Preto (RPSP); Coleção Entomológica Padre Jesus Santiago Moure of the Universidade Federal do Paraná, Curitiba (DZUP); and the Laurence Packer Collection of the York University, Toronto (PCYU). Those bees were examined under a Leica M125 ${ }^{\circledR}$ dissection microscope in search for distinctive taxonomic characters. Male genitalia of most species were dissected for study as described in Freitas and Silveira (2017).

The following species were employed as the ingroup in the analyses described below: Thygater anae Urban 1999, Thygater armandoi Urban 1999, Thygater chaetaspis Moure 1941, Thygater latitarsis Urban 1967, Thygater luederwaldti (Schrottky 1910), Thygater minarum Urban 1999, Thygater palliventris (Friese 1908), and Thygater paranaensis Urban 1967. Additionally, a few distinct morphospecies, all identifiable as T. analis (Lepeletier 1841), were also included in the analyses. Of the 15 species of Thygater known to occur in Brazil, these are all for which material could be obtained for molecular analysis.

Trichocerapis mirabilis (Smith 1865) was chosen as the outgroup, considering that the genus is part of a putative clade in Eucerini, also including Thygater, the so-called Thygater-Trichocerapis group (Urban 1967; Michener 2007).

An effort was made to extract DNA from the largest possible number of specimens of each species. For abundant taxa, newer specimens were preferred for maximum extraction efficiency. DNA samples were extracted from legs taken from dry specimens, using the phenol-chloroform method (Sambrook \& Russel 2001). The cytochrome oxidase I (COI) was then amplified, using the primers LepF1 and LepR1 (Hebert et al. 2004) and mtd_6 and mtd 9 (Simon et al. 1994). Amplification was done in $15 \mu \mathrm{L}$ polymerase chain reaction (PCR) mix, including 5 units of Taq polymerase, $0.6 \mu \mathrm{L}$ of $\mathrm{MgCl}_{2}(50 \mathrm{mM}), 1.5 \mu \mathrm{L}$ of PCR buffer $(10 \times)$, $0.5 \mu \mathrm{L}$ of each primer $(25 \mu \mathrm{M}), 1.2 \mu \mathrm{L}$ of dNTPs (2.5 mM), and about $1 \mu \mathrm{L}$ of genomic DNA (20 ng). Amplification was carried out using a thermocycler program consisting of $5 \mathrm{~min}$ of denaturation at $94{ }^{\circ} \mathrm{C}$, followed by 37 cycles of $30 \mathrm{~s}$ at $94{ }^{\circ} \mathrm{C}$, $40 \mathrm{~s}$ at $48-50{ }^{\circ} \mathrm{C}, 1.30 \mathrm{~min}$ at $72{ }^{\circ} \mathrm{C}$, and a final extension for $10 \mathrm{~min}$ at $72{ }^{\circ} \mathrm{C}$. PCR products were visualized in a $2 \%$ agarose gel. All PCRs that generated a single product were purified using $20 \%$ polyethylene glycol (PEG) precipitation (Santos Júnior et al. 2015). Sequencing reactions were carried out using BigDye ${ }^{\circledR}$ version 3.1 in both directions using an ABI 3130xl Genetic Analyzer ${ }^{\circledR}$ sequencer, with the same amplification primers, and following the manufacturer's recommendations. 
Table I. Specimens employed in the phylogenetic analyses performed here

\begin{tabular}{|c|c|c|c|c|c|c|}
\hline \multirow[t]{2}{*}{ Species } & \multirow[t]{2}{*}{ ID } & \multirow[t]{2}{*}{ Sex } & \multicolumn{2}{|c|}{ Depository collection } & \multirow{2}{*}{$\begin{array}{c}\text { Locality } \\
\text { (country-state/ } \\
\text { province) }\end{array}$} & \multirow{2}{*}{$\begin{array}{c}\text { GenBank } \\
\text { access } \\
\text { number }\end{array}$} \\
\hline & & & Acronym & Access no. & & \\
\hline \multirow[t]{3}{*}{ T. anae } & 1 & Female & UFMG & IHY 38332 & Brazil—Minas Gerais & MF544041 \\
\hline & 2 & Female & UFMG & IHY 65124 & Brazil—Rio de Janeiro & MF544042 \\
\hline & 3 & Male & UFMG & IHY 1200097 & Brazil—Rio de Janeiro & MF544043 \\
\hline \multirow[t]{11}{*}{ T. analis } & 4 & Male & UFMG & IHY 1217311 & Brazil_Paraiba & MF544044 \\
\hline & 5 & Male & UFMG & IHY 1217358 & Brazil_Paraiba & MF544045 \\
\hline & 6 & Female & UFMG & IHY 1300785 & Brazil—Minas Gerais & MF544046 \\
\hline & 7 & Male & UFMG & IHY 1316999 & Brazil—Rio de Janeiro & MF544047 \\
\hline & 8 & Male & UFMG & IHY 1317001 & Brazil—Rio de Janeiro & MF544048 \\
\hline & 9 & Male & UFMG & IHY 1402951 & Brazil-Minas Gerais & MF544049 \\
\hline & 10 & Male & UFMG & IHY 1530265 & Brazil—Santa Catarina & MF544050 \\
\hline & 11 & Male & UFMG & IHY 1600325 & Brazil-Minas Gerais & MF544051 \\
\hline & 12 & Male & UFMG & IHY 1208352 & Brazil—Minas Gerais & MF544052 \\
\hline & 13 & Female & PCYU & NSV 4971 & Argentina-Misiones & MF544053 \\
\hline & 14 & Female & PCYU & NSV 3243 & Argentina-Formosa & MF544054 \\
\hline \multirow[t]{6}{*}{ T. carijo sp. n. } & 15 & Male & UFMG & IHY 1200664 & Brazil—Santa Catarina & MF544055 \\
\hline & 16 & Male & UFMG & IHY 1200675 & Brazil—Santa Catarina & MF544056 \\
\hline & 17 & Female & UFMG & IHY 1200670 & Brazil—Santa Catarina & MF544057 \\
\hline & 18 & Female & UFMG & IHY 1200704 & Brazil—Santa Catarina & MF544058 \\
\hline & 19 & Female & UFMG & IHY 1200686 & Brazil—Santa Catarina & MF544059 \\
\hline & 20 & Male & UFMG & IHY 1200689 & Brazil—Santa Catarina & MF544060 \\
\hline \multirow[t]{4}{*}{ T. chaetaspis } & 21 & Female & UFMG & IHY 37872 & Brazil—Rio de Janeiro & MF544061 \\
\hline & 22 & Female & UFMG & IHY 38303 & Brazil—Espirito Santo & MF544062 \\
\hline & 23 & Macho & UFMG & IHY 38306 & Brazil—Espirito Santo & MF544063 \\
\hline & 24 & Female & UFMG & IHY 38338 & Brazil—Minas Gerais & MF544064 \\
\hline \multirow[t]{4}{*}{ T. minarum } & 25 & Female & UFMG & IHY 37965 & Brazil—Minas Gerais & MF544065 \\
\hline & 26 & Male & UFMG & IHY 53640 & Brazil—Minas Gerais & MF544066 \\
\hline & 27 & Male & UFMG & IHY 53641 & Brazil—Minas Gerais & MF544067 \\
\hline & 28 & Male & UFMG & IHY 53642 & Brazil—Minas Gerais & MF544068 \\
\hline \multirow[t]{11}{*}{ T. palliventris } & 29 & Male & UFMG & IHY 53700 & Brazil—Minas Gerais & MF544069 \\
\hline & 30 & Female & UFMG & IHY 1205207 & Brazil—Minas Gerais & MF544070 \\
\hline & 31 & Male & UFMG & IHY 1500415 & Brazil-Minas Gerais & MF544071 \\
\hline & 32 & Male & UFMG & IHY 1500418 & Brazil—Minas Gerais & MF544072 \\
\hline & 33 & Male & UFMG & IHY 1500419 & Brazil—Minas Gerais & MF544073 \\
\hline & 34 & Male & UFMG & IHY 1500422 & Brazil-Minas Gerais & MF544074 \\
\hline & 35 & Female & UFMG & IHY 1501392 & Brazil—Minas Gerais & MF544075 \\
\hline & $36^{*}$ & Female & UFMG & IHY 1530285 & Brazil—Santa Catarina & MF544076 \\
\hline & 37 & Female & UFMG & IHY 1530286 & Brazil—Santa Catarina & MF544077 \\
\hline & 38 & Male & UFMG & IHY 1600305 & Brazil-Minas Gerais & MF544078 \\
\hline & 39 & Male & PCYU & NSV 3502 & Argentina-Misiones & MF544079 \\
\hline \multirow[t]{2}{*}{ T. paranaensis } & 40 & Female & UFMG & IHY 1200448 & Brazil—Santa Catarina & MF544080 \\
\hline & 41 & Female & UFMG & IHY 1200449 & Brazil-Santa Catarina & MF544081 \\
\hline
\end{tabular}


Table I (continued)

\begin{tabular}{|c|c|c|c|c|c|c|}
\hline \multirow[t]{2}{*}{ Species } & \multirow[t]{2}{*}{ ID } & \multirow[t]{2}{*}{ Sex } & \multicolumn{2}{|c|}{ Depository collection } & \multirow{2}{*}{$\begin{array}{c}\text { Locality } \\
\text { (country-state/ } \\
\text { province) }\end{array}$} & \multirow{2}{*}{$\begin{array}{c}\text { GenBank } \\
\text { access } \\
\text { number }\end{array}$} \\
\hline & & & Acronym & Access no. & & \\
\hline & 42 & Female & UFMG & IHY 65133 & Brazil_-Rio de Janeiro & MF544082 \\
\hline & 43 & Female & UFMG & IHY 92245 & Brazil-Minas Gerais & MF544083 \\
\hline & 44 & Female & UFMG & IHY 1200451 & Brazil_-Santa Catarina & MF544084 \\
\hline T. danunciae & 45 & Male & UFMG & IHY 76767 & Brazil-Minas Gerais & MF544085 \\
\hline \multirow[t]{2}{*}{ T. luederwaldti } & 46 & Female & UFMG & IHY 39828 & Brazil-Minas Gerais & MF544086 \\
\hline & 47 & Female & PCYU & 06728H10_BRA & Brazil-Minas Gerais & MF544087 \\
\hline \multirow[t]{3}{*}{ T. latitarsis } & $48 *$ & Male & UFMG & IHY 37922 & Brazil_-Rio de Janeiro & MF544088 \\
\hline & 49 & Female & UFMG & IHY 37880 & Brazil_-Rio de Janeiro & MF544089 \\
\hline & 50 & Female & UFMG & IHY 37923 & Brazil_-Rio de Janeiro & MF544090 \\
\hline $\begin{array}{l}\text { Trichocerapis } \\
\text { mirabilis }\end{array}$ & 51 & Male & UFMG & IHY 65105 & Brazil-Minas Gerais & MF544091 \\
\hline
\end{tabular}

The specimens marked with asterisk were previously identified as T. nigrilabris (27), which is synonymized to T. latitarsis, and T. armandoi (36), synonymized to T. palliventris

The consensus sequences were obtained using the software SeqScape ${ }^{\circledR}$ v2.6. At least two sequencing reactions were done in each direction to help in the elucidation of doubts concerning chromatogram interpretation. A complete list of the specimens employed in the phylogenetic analyses from which DNA was extracted and sequenced is given in Table I.

\subsection{Matrix construction}

COI sequences were aligned using the algorithm MUSCLE (Edgar 2004) with the default settings in MEGA 7 (Kumar et al. 2016), resulting in an alignment of $726 \mathrm{bp}$. After that, the matrix was submitted to the algorithm Gblocks (Castresana 2000), in the online server http://molevol.cmima.csic. es/castresana/Gblocks_server.html, with all options to a less stringent selection marked ("Allow smaller final blocks," "Allow gap positions within the final blocks," and "Allow less strict flanking positions") to reduce the missing data in the extremities of the alignment, resulting in a new matrix, now with 652 $\mathrm{bp}$, that was used in the phylogenetic analyses.

The nucleotide substitution models and partitioning schemes were chosen with the aid of the software PartitionFinder2 (Lanfear et al. 2016), with each COI codon position included as a partition, the branch lengths unlinked, BIC as the criterion for model selection, and "greedy" as the option for best scheme searching.

Phylogenetic analyses were conducted using the online server CIPRES (https://www.phylo. org/portal2/home.action; Miller et al. 2010). Maximum likelihood (ML) analysis was conducted using RAxML 8.2.9 (Stamatakis 2014) with 100 starting trees and the bootstrap configured to halt automatically with the auto RME criterium. The substitution model used for each partition (COI codon positions) was the GTR + GAMMA (the only one implemented). Default parameters were used in all other instances. Bayesian inference (BI) was performed with MrBayes 3.2.6 (Ronquist et al. 2012) using two independent runs with 10 million generations, with four Markov chains each, and a $25 \%$ burn-in. HKY + GAMMA, F81 + I, and HKY + GAMMA were the models indicated by PartitionFinder2 and used for each one of the partitions in sequence. Other parameters were the default ones. Convergence for BI analysis was checked using Tracer 1.6 (Rambaut, et al. 2014); ESS values were confirmed to be all above 200 .

Average intra- and interspecific genetic distances were obtained for all species analyzed. For this, DNA originally extracted for this paper and COI data available in GenBank and BOLD online databases were employed (sequence access numbers are available in the supplementary 
material). Since sequencing primers used to generate these sequences were not always the same, only the $379 \mathrm{bp}$ present in all sequences were employed here. Genetic distances were calculated with MEGA 7 (Kumar et al. 2016), using the Kimura two-parameter (K2P) model with 1000 bootstrap replications (Nei and Kumar 2005). Intraspecific distances were estimated only for species represented by three or more specimens and with at least two different haplotypes.

In the diagnoses and description below, the morphological nomenclature employed was generally that of Michener (2007), except that the divisions of the antennal flagellum were called "flagellomeres" instead of "flagellar segments" and were usually abbreviated to F1, F2, etc. Similarly, divisions of the palpi were called palpomeres. Metasomal terga and sterna were called T1, T2, etc., and S1, S2, etc., respectively. Additionally, terminology referring to male genitalia follows Urban (1967). Distance between punctures is expressed as number of diameters of a puncture (dp).

In the taxonomic sections of this paper, information on the holotype is reproduced as presented on its labels, with information in different lines of a label separated by semicolons, and information from each label separated by double quotes. Information on the other examined specimens is given in the following format: country-state: municipality — specific locality (when available), collection date (as dd/mm/yyyy), collector name, number of females and males examined [acronym of the depository collection]. Information on specimens collected in each municipality is separated by a semicolon from those referring to specimens collected in the same municipality but on different dates, and/or by different collectors.

The diagnostic characters found for each of the species or sexes recognized here are in boldface in the diagnoses presented in the taxonomic results below.

\section{RESULTS}

\subsection{Phylogenetic analyses}

The results of both analyses [ML (Fig. S1 supplementary material) and BI (Figure 1)] were congruent in three different ways: (1) both recovered all the species previously recognized morphologically, as well as the candidate new species (T. carijo sp. n., see Section 3.3), as reciprocally monophyletic; (2) both suggested the same sex associations for all the species for which male and female were included in the analyses; and (3) both grouped the species in two major, strongly supported clades with the same species composition.

The analyses also indicated that males of $T$. analis and those of $T$. palliventris were being confused (males of the latter were unknown until now). Moreover, they allowed for the identification of male Thygater danunciae [described in Freitas and Silveira (2017) and identified with the support of these results] and T. carijo sp. n. Males of both species were previously identified as T. analis with the use of Urban's (1967) key to the species of Thygater. Genetic separation of the males of these four species led to their careful examination and to the discovery of subtle morphological characters allowing for their distinction. These characters were employed in the description of T. carijo sp. n. (see Section 3.3) and in another taxonomic study of Thygater (Freitas and Silveira 2017). The genetic analyses also lead to the recognition of males of $T$. minarum, a species known only by its females until now (Urban 1999; Urban et al. 2012). Moreover, the results also confirmed the preliminary suspicion by Freitas and Silveira (2017), based on morphological similarity, that T. armandoi and Thygater nigrilabris were junior synonyms of $T$. palliventris and T. latitarsis, respectively.

The only difference between ML and BI results was the position of the specimens of $T$. anae and T. minarum, which were sister species, sister to the remaining species in the clade ( $T$. danunciae, T. analis, $T$ carijo sp. n., and T. palliventris) in the BI result (see Figure 1), while in the ML tree, T. minarum was sister to $T$. anae + the remaining species in the clade.

\subsection{Genetic distances}

Thygater paranaensis presented the largest average intraspecific distance $(0.50 \% \pm 0.25$, Table S1 Supplementary Material); however, this is still smaller than the smallest average interspecific distances, those between $T$. analis and 


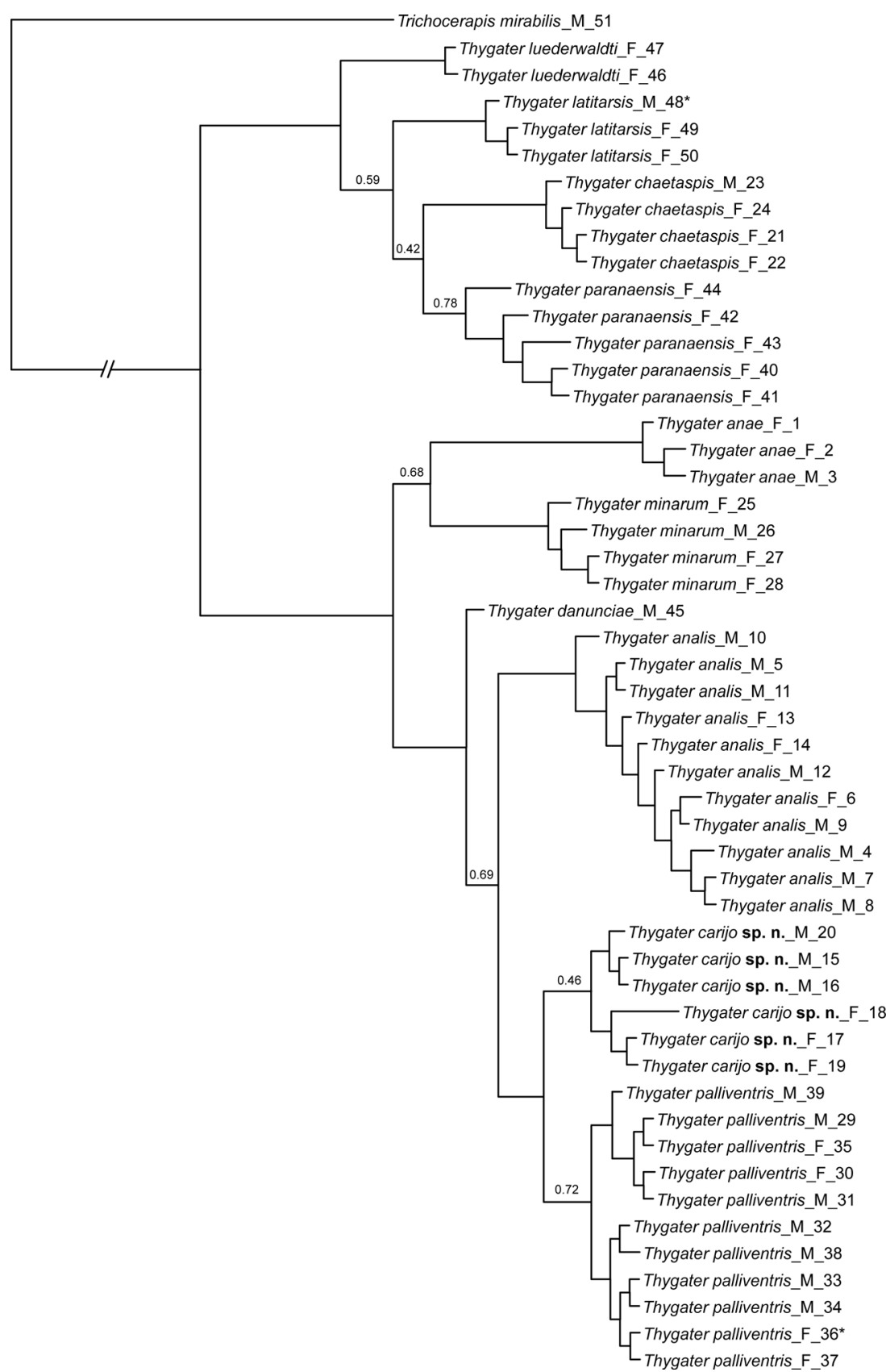

Figure 1. Consensus tree resulting from Bayesian inference. All posterior probabilities above $95 \%$ and those inside the clades corresponding to the species were omitted. The branch between the outgroup and the ingroup was shortened so that the tree would fit in the page. Males attributed to T. minarum in the tree were previously undescribed; males attributed to T. palliventris and T. danunciae and males and females attributed to T. carijo sp. n. were previously identified as T. analis . Specimen 36-F included among T. palliventris was formerly identified as $T$. armandoi (now a junior synonym of $T$. palliventris), and specimen 48-M was previously identified as T. nigrilabris (synonymized to T. latitarsis), both of them are marked with an asterisk. The specimen ID numbers are those in Table I. The letters $\mathrm{M}$ and $\mathrm{F}$ in the specimen codes identify males and females, respectively. 
T. danunciae $(0.80 \% \pm 0.55)$, between T. palliventris and T. danunciae $(0.83 \% \pm 0.45)$, between $T$. carijo $\mathrm{sp}$. n. and $T$. palliventris $(0.88 \% \pm 0.45)$, and between $T$. carijo sp. n. and T. danunciae $(1.05 \% \pm 0.50)$ (Table S1 Supplementary Material).

\subsection{Taxonomic results}

Thygater carijo sp. n. is described; males of T. palliventris and T. minarum are diagnosed (their complete descriptions, as well as the description of $T$. danunciae, were presented elsewhere (Freitas and Silveira 2017)).

\subsubsection{Thygater palliventris (Friese 1908) (Figures $2 a-c$ and $4 b, e$ )}

Tetralonia palliventris Friese 1908, p. 47

Thygater (Thygater) palliventris (Moure \& Michener 1955; Urban 1967; Moure et al. 2012)

Thygater (Thygater) armandoi Urban 1999, p. 219

Diagnosis (male)Labrum yellowish (Figure 2a); basal depression of clypeus short (one fifth of clypeal length; Figure 2a); pilosity of mesosoma always predominantly whitish
(Figure 2a-c); hind basitarsus parallel-sided; pilosity on marginal zones of $\mathrm{T} 5$ and $\mathrm{T} 6$ always white; apical emargination of $\mathrm{T} 7$ deep, separating two triangular lobes; marginal fringe of S4 incomplete; fringe of thick setae present only along posterior margin of proximal lobe of median plate of S7, absent on the anterior margin of distal lobe (Figure $4 \mathrm{~b}$ ); proximal lobe of S7 wide, its anterior margin bulging, anterior and lateral margins meeting on a wide angle (Figure 4b). Thygater palliventris can be confused with those males of $T$. analis with predominantly white pilosity on T4-T7 but can be distinguished from them by the characters in S7 highlighted above. These two species are sympatric throughout the known range of T. palliventris .

Examined materialArgentina-Misiones: Puerto Iguazu-Parque Nacional Iguazu (17 July 2009), N. Veiga, $1 \delta^{\Uparrow}$ [PCYU]. Brazil-Minas Gerais: Alto Caparaó (12 March 2015), J. E. SantosJunior and J. C. Oliveira, 1ठ [UFMG]; CaldasPedreira Juparana (10 November 2014), B. C.

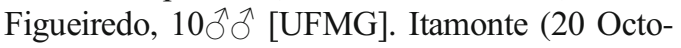
ber 2006), M.F. Goulart, $1 \bigcirc$ [UFMG]. Nova Lima (12 May 2015), A. R. Lima, $1 \delta^{\Uparrow}$ [UFMG]; 26
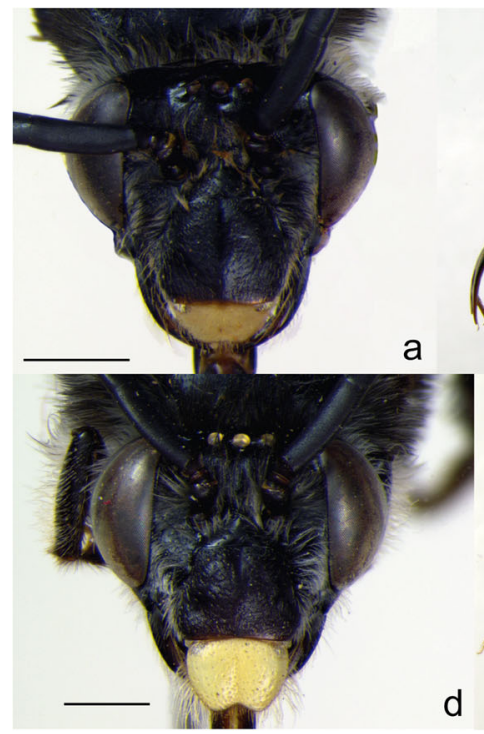
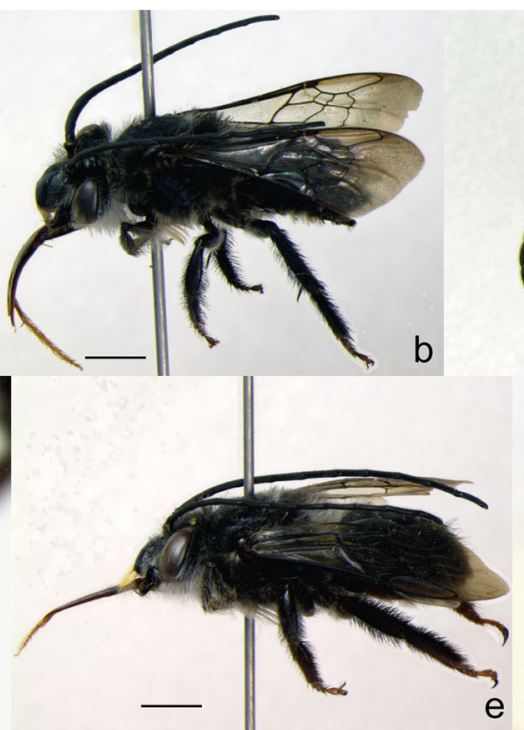
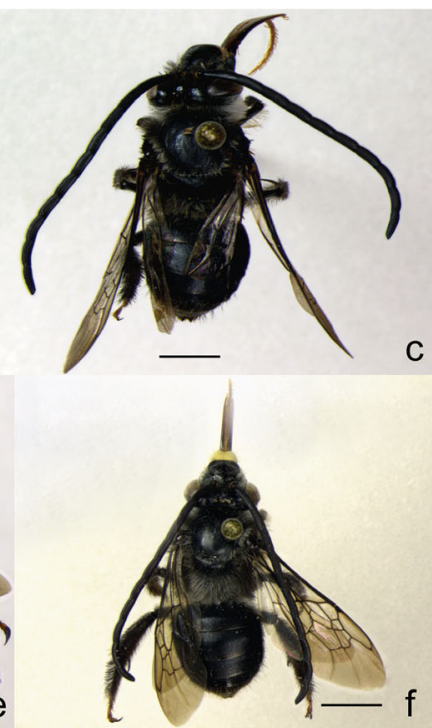

Figure 2. a-c Male of T. palliventris (UFMG IHY 1602166). a Frontal view. b Lateral view. c Dorsal view. d-f Male of T. minarum (UFMG IHY 53639). d Frontal view. e Lateral view. f Dorsal view. Scale bars = 1 mm. 
April 2015, A. R. Lima, $1 \lesssim$ [UFMG]. Sabará (24 November 1996), F. A. Silveira, $1 \lesssim$ [UFMG]. Santa Maria do Salto (13 February 2009), A. Nemésio (13 February 2009), $1 \delta^{\widehat{C}}$ [UFMG]; 14

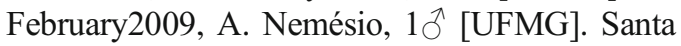
Catarina: São Francisco do Sul-Bairro Vila da Glória (20 December 2011), F. A. Silveira, 2ðð [UFMG]. São Paulo: Bauru-UNESP (1 July 1994), F. Knoll, 1 ð̊ [UFMG].

\subsubsection{Thygater minarum Urban 1999 (Figures $2 d-f$ and $4 c, f$ )}

Thygater (Thygater) minarum Urban 1999, p. 217; Moure et al. 2012

Diagnosis (male)Males of T. minarum can be confused with those of $T$. analis and T. palliventris, from which they can be distinguished by the projections of the apical margin of T7, which are rounded in T. minarum and triangular in those other species; by the presence of a fringe of very thick setae present only along the posterior margin of the proximal lobe of median plate of S7 (Figure 4c), those setae thicker than in any other Brazilian species of the genus.

Examined materialBrazil-Bahia: $8 \mathrm{~km}$ from Camacã-Serra Bonita (21 January 2011), G. Melo, $6{ }^{\wedge}$ [DZUP]. Prado (5 November 1971), C. Elias, 7ð̄ [DZUP]. Minas Gerais: Santa Maria do Salto (13 February 2009), A. Nemésio, 7ठえた; 14 February 2009, A. Nemésio, 1ठ [UFMG].

\subsubsection{Thygater carijo Freitas \& Silveira sp. n. (Figures 3 and 4a, d)}

Holotype (†): "Brasil, SC, São Francisco; do Sul, B. Vila da Glória; $26^{\circ} 13^{\prime} 17.4^{\prime \prime}$ S; $48^{\circ} 41^{\prime}$ 11.3" W; 20.xii.2011. Em flor; F. A. Silveira. UFMG IHY 1200666"; "Holotypus; Thygater (Thygater) carijo 9 ; F.V. Freitas \& F. A. Silveira 2018". At UFMG.

Paratypes (3qq and $\left.4 \delta^{\lambda}\right)$ : "Brasil, SC, São Francisco do Sul, B. Vila da Glória, 26 $6^{\circ} 13^{\prime} 17.4^{\prime \prime}$ S; $48^{\circ} 41^{\prime}$ 11.3" W. 20.xii.2011. Em flor. F. A.

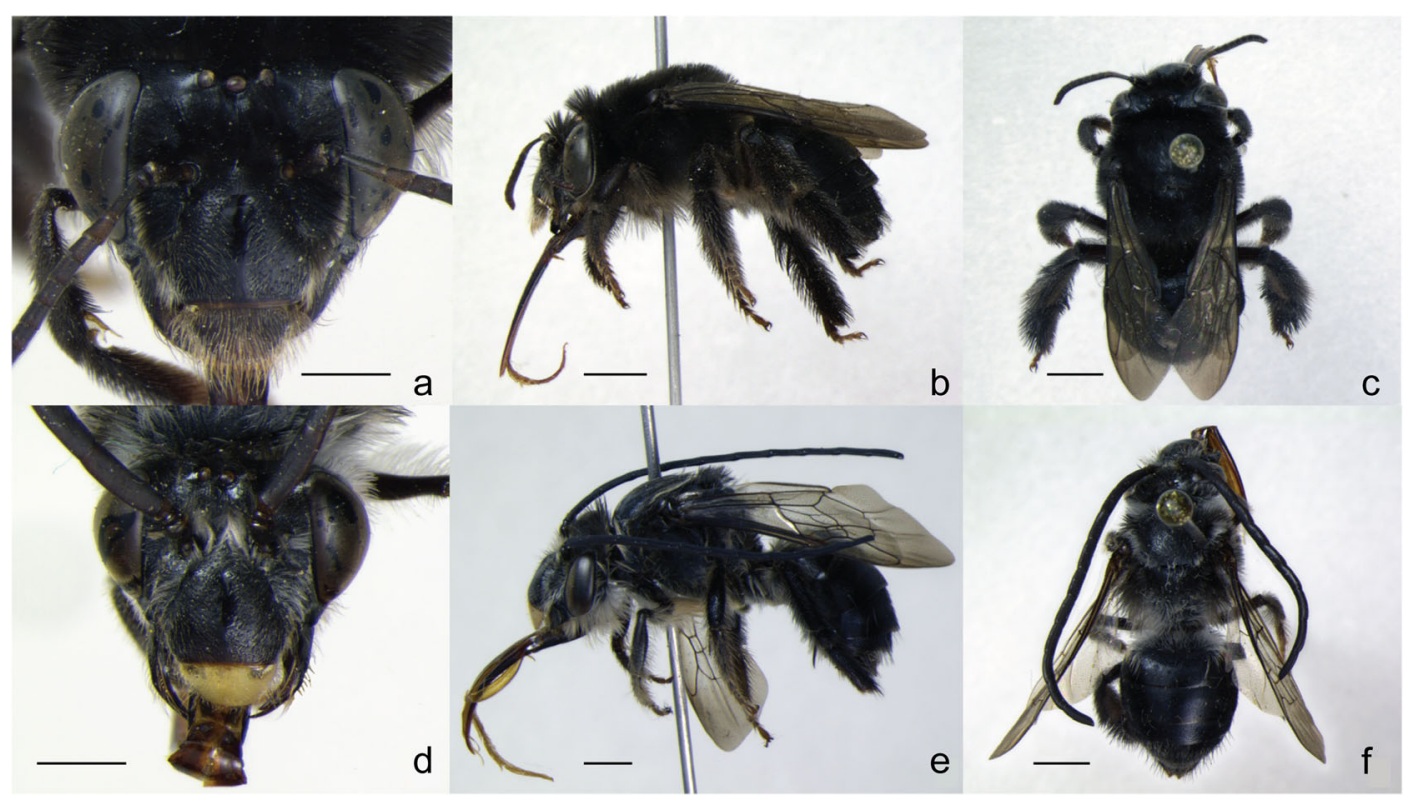

Figure 3. T. carijo sp. n. Female (holotype, UFMG IHY 1200666). a Frontal view. b Lateral view. c Ventral view. Male (paratype, UFMG IHY 1200664). d Frontal view. e Lateral view. f Ventral view. Scale bars $=1 \mathrm{~mm}$. 


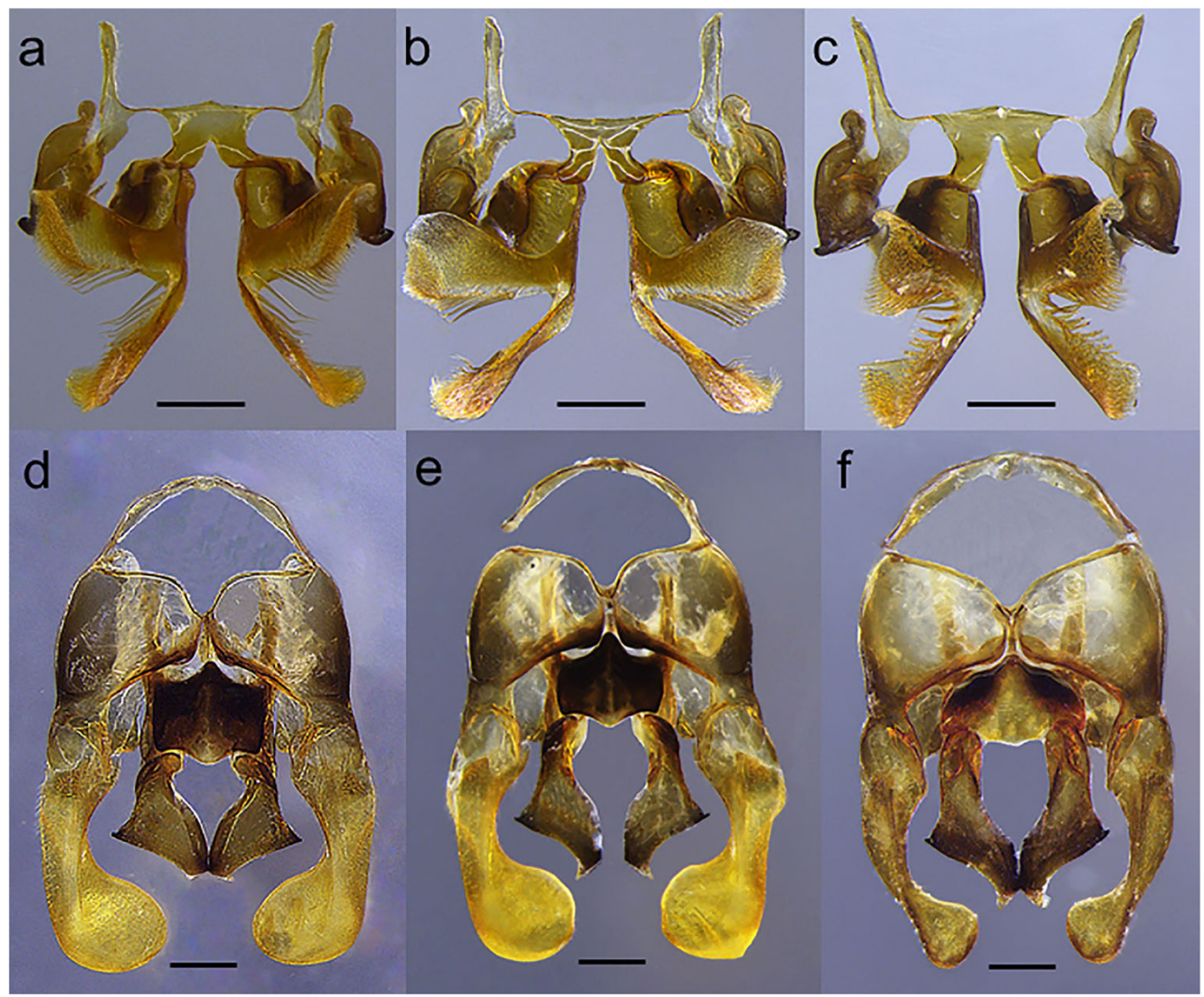

Figure 4. Seventh sterna (a-c) and genitalia (d-f) of a, d Thygater carijo sp. n. (UFMG IHY 1200664); b, e T. palliventris (UFMG IHY 1602166); and c, f T. minarum (UFMG IHY 53639). Scale bars $=500 \mu \mathrm{m}$.

Silveira. UFMG-IHY-1200664, 1200670 , $1200675,1200686,1200689,1200690$, 1200704".

Etymology: Homage to the Carijó Indians, original inhabitants of the coastal lands that encompass the type locality.

Flower records: unknown.

DiagnosisFemales of $T$. carijo sp. n. can be distinguished mainly for their completely black integument and almost completely black pilosity (Figure $3 \mathrm{a}-\mathrm{c})$. They have a smooth midlongitudinal stripe on clypeal integument, which never reaches the apex of clypeus (Figure 3a) similar to that in $T$. palliventris, but in this latter species, the integument is yellowish or brownish, never black as in T. carijo sp. n. Males may be confused with $T$. analis and T. palliventris, but the pilosity of F1 is golden in T. carijo sp. n. and black or fuscous in the two other species. Besides that, T. carijo sp. $\mathrm{n}$. has the median plate of S7 with thick setae along the posterior margin of its proximal lobe and the anterior margin of its distal lobe, these setae almost reaching the base of both lobes, as shown in Figure $4 \mathrm{a}$; in $T$. analis and T. palliventris, those setae never reach the base of those lobes (Figure 4b).

Description $q$ (holotype)Measurements ( $\mathrm{mm}$ ): total body length, 13.0; maximum head width, 4.9; largest distance between the external margins of tegulae, 5.2; length and width of clypeus, 1.5 and 2.2 , respectively; inter antennal distance, 1.1 ; malar area, 0.3 (one fourth width of mandibular base); maximum labrum width, 1.8. Integument black, except translucent-amber on apex of 
marginal zones of terga and sterna; on clypeus densely punctate, reticulate on basal two thirds, except for smooth mid-longitudinal stripe; mesosoma reticulate, densely punctate $(<1 \mathrm{dp})$; metasoma lineolate, finely and densely punctate $(<1 \mathrm{dp})$; marginal depression of terga smooth. Pilosity black, except whitish on labrum, laterally on clypeus, lower paraocular area, gena near the posterior eye margin, and on lateral tufts of $\mathrm{S} 3$ and $\mathrm{S} 4$; fuscous on venter of mesosoma and metasoma; on mesosoma dense; on metasoma sparse, with predominantly simple setae on terga; T5 with thick, long setae mixed with plumose ones; sterna with complete apical fringe, especially dense on S5. Structure - clypeus gently convex, with light longitudinal, preapical elevation, its basal depression reaching one third of clypeal length; marginal zone of terga short (shorter than F2), except that of T1, almost as long as pedicel; translucent-amber areas on apex of marginal zone of sterna short, shorter than pedicel; S6 with midlongitudinal carina.

đิ (UFMG IHY 1200664, Brazil, Santa Catarina, São Francisco do Sul, B. Vila da Glória, 20.xii.2011. Em flor. F. A. Silveira). Integument black, except whitish-yellow on labrum; head reticulate, except smooth on mid-longitudinal stripe (almost as wide as the length of F1) of clypeus, and around ocelli; mesosoma reticulate and densely punctate $(\approx 1 \mathrm{dp})$, mesoscutum somewhat shining, with lighter reticulation; metasoma strongly reticulate, especially on terga, somewhat shining with lighter reticulation on sterna; terga finely and sparsely punctate $(\approx 1.5 \mathrm{dp})$, sterna still finer and sparser. Pilosity fuscous, except golden on F1, white on head, pronotum, axillae, posterior margin of mesoscutum, metanotum, propodeum, all venter and including forelegs, coxa, trochanter, and femur of mid and hind legs, and T1 basally; black apically on T1 and on T2-T4 throughout; a mixture of black and white hairs on T5-T7, the white ones more abundant on disc; on T2-T4 forming medially-interrupted fringes; on T5 reduced to lateral tufts; on T6 forming an hourglass-shaped patch of simple and short hairs. Structure - malar area two thirds as long as basal mandibular width; clypeus slightly convex on disc, its basal depression reaching one third of clypeal length; translucent-amber areas on apex of marginal zones short, S5 without marginal projections; S6 without lateral and mid-longitudinal carinae; T7 deeply emarginate forming two flat triangular projections.

\section{DISCUSSION}

The genetic divergences between some of the species of Thygater were relatively small, even if compared to species in other genera of Eucerini (Table S2 Supplementary Material). However, there are other examples of bee taxa with small genetic distances between closely related species, for example Bombus (Santos Júnior et al. 2015 and references therein), Dialictus (Gibbs 2009a), and Euglossina (Dick et al. 2004; Nemésio et al. 2013). As in other bee groups, a "barcode gap" can be identified, with interspecific distances being always larger than the largest intraspecific distances. Of course, this gap by itself is not irrefutable evidence for species distinction (e.g., Čandek and Kuntner 2014; Magnacca and Brown 2010; Meyer and Paulay 2005; Wiemers and Fiedler 2007) but gives additional support to the recognition of sibling species, when considered with other sources of evidence, such as the reciprocal monophyly of species, and the recognition of morphological autapomorphies or consistent diagnostic characters (see also Freitas and Silveira (2017)).

In the opposite direction, analyses of molecular data gave additional support to the recognition of synonyms when species were originally distinguished by subtle characters (Urban 1999), which were found to be variable (see a discussion of these characters in Freitas and Silveira (2017)).

The analyses above also corroborated the sex associations suggested by previous authors for the species of Thygater and allowed new associations, reinforcing the utility of the genetic barcode as an auxiliary tool in systematics, especially in sex association, a hard task in the taxonomy of 
highly sexual dimorphic insects, as already shown for other invertebrates (e.g., Barrett and Hebert 2005; Carolan et al. 2012; Koch 2010; Packer et al. 2009; Ståhls et al. 2009) and especially bees (e.g., Carolan et al. 2012; Gibbs 2009a, b; Williams et al. 2012).

Regarding the phylogenetic relations of the species employed here, the two major, strongly supported clades could coincide with the subgenera currently accepted in the classifications of Thygater (Urban et al. 2012; Michener 2007; Ascher and Pickering 2017). However, our results do not corroborate the distinction made by Urban (1967) between the subgenera Thygater s. str. and Thygater (Nectarodiaeta), based upon the number of maxillary palpomeres [Thygater s. str. having three and Thygater (Nectarodiaeta) four]. Thus, T. paranaensis and $T$. chaetaspis, species with three maxillary palpomeres, grouped with $T$. latitarsis and $T$. luederwaldti, the only species with four palpomeres included in the analyzes. Michener (2007) already questioned the classification proposed by Urban (1967), suggesting that, thus defined, the subgenera would not be monophyletic. Here, no taxonomic decision on the subgeneric classification of Thygater is made, because more taxa and characters (both molecular and morphologic) would be required to produce a robust phylogenetic hypothesis and that was not the aim of this study. Such analysis is being undertaken by the authors.

\section{ACKNOWLEDGEMENTS}

We thank Clemens Schlindwein (Department of Botany, UFMG), Eduardo A. B. Almeida (RPSP), Gabriel Melo (DZUP), Laurence Packer (PCYU), and Lucio A. O. Campos (UFV) for the loan of specimens. Special thanks are due to Eduardo A.B Almeida and Daniel M. Casali for the discussions on the analyses and on the manuscript. We also thank Danuncia Urban and Gabriel A. R Melo for the elucidation of several doubts on the characters and species identity, to Igor Rodrigues and Fernanda Trancoso for helping with the figure preparation, and to the two anonymous reviewers for the relevant contributions.

\section{AUTHOR CONTRIBUTIONS}

FVF and FAS conceived this research. FVF and JESJ performed the experiments and analyzed the data. FRS and FAS contributed with the reagents, materials, and analysis tools. FVF and FAS wrote the paper. All authors read and approved the final manuscript.

\section{FUNDING INFORMATION}

We are indebted to the Fundação de Amparo à Pesquisa de Minas Gerais (FAPEMIG) and the Conselho Nacional de Pesquisa (CNPq) for the financial support and to the Coordenação de Aperfeiçoamento de Pessoal de Nível Superior (CAPES) for the scholarship granted to FVF.

Délimitation d'espèces et associations sexuelles dans le genre Thygater à l'aide de données moléculaires, et description d'une nouvelle espèce

Apoidea / Dimorphisme sexuel / Eucerini / Néotropiques / Nouveau synonyme / Monophylie réciproque / Délimitation des espèces

B e stim mung on A r t grenzen und Geschlechtsmerkmalen in der Bienengattung Thygater mithilfe molekularer Daten, und die Beschreibung einer neuen Art

Apoidea / Geschlechtsdimorphismus / Eucerini / Neotropen / neues Synonym / reziproke Monophylie / Artgrenzen

\section{REFERENCES}

Ascher, J. S., Pickering, J. (2017) Discover Life bee species guide and world checklist (Hymenoptera: Apoidea: Anthophila) [online] http://www.discoverlife. org $/ \mathrm{mp} / 20 \mathrm{q}$ ?guide=Apoidea_species $($ Accessed on 09 October 2017)

Barrett, R. D. H., Hebert, P. D. N. (2005). Identifying spiders through DNA barcodes. Can. J. of Zool., 83, 481-491

Čandek, K., Kuntner, M. (2014). DNA barcoding gap: reliable species identification over morphological 
and geographical scales. Mol. Ecol. Resour., 15 268-277

Carolan, J. C., Murray, T. E., Fitzpatrick, Ú., Crossley, J., Schmidt, H., et al. (2012). Colour patterns do not diagnose species: quantitative evaluation of a DNA barcoded cryptic bumblebee complex. PLoS ONE, 7 (1), e29251

Castresana, J. (2000). Selection of conserved blocks from multiple alignments for their use in phylogenetic analysis. Mol. Biol. and Evol., 17, 540-552.

Dayrat, B. (2005). Towards integrative taxonomy. Biol. J. Linn. Soc., 85, 407-415

Dick, C. W., Roubik, D. W., Gruber, K. F., Bermingham, E. (2004). Long-distance gene flow and cross-Andean dispersal of lowland rainforest bees (Apidae: Euglossini) revealed by comparative mitochondrial DNA phylogeography. Mol. Ecol., 13 , 3775-3785

Duda Jr., T. F., Bolin, M. B., Meyer, C. P., Kohn, A. J. (2008). Hidden diversity in a hyperdiverse gastropod genus: Discovery of previously unidentified members of a Conus species complex. Mol. Phylo. Evol., 49 (3), $867-876$

Edgar, R. C. (2004). MUSCLE: multiple sequence alignment with high accuracy and high throughput. Nucl. Acids Res., 32 (5), 1792-97

Fontaneto, D., Kaya, M., Herniou, E. A., Barraclough, T. G. (2009). Extreme levels of hidden diversity in microscopic animals (Rotifera) revealed by DNA taxonomy. Mol. Phylo. Evol., 53 (1), 182-189

Freitas, F. V., Silveira F. A. (2017). Synopsis of the bee genus Thygater Holmberg 1884 (Hymenoptera, Apidae) in the Brazilian state of Minas Gerais, with the description of a new species and a key to all Brazilian species. Zootaxa, 4238 (1): 001-029

Friese, H. (1908). Die Apidae (Blumenwespen) von Argentina nach den Reisenergebnissen der Herren A. C. Jensen-Haarup und P. Jörgensen in den Jahren 19041907 [Apidae from Argentina, collected in the travels of mrs. A. C. Jensen and P. Jorgensen between the years 1904-1907]. Flora og Fauna, 10, 1-94

Gibbs, J. (2009a). Integrative taxonomy identifies new (and old) species in the Lasioglossum (Dialictus) tegulare (Robertson) species group (Hymenoptera, Halictidae). Zootaxa, 2032, 1-38

Gibbs, J. (2009b). New species in the Lasioglossum petrellum species group identified through an integrative taxonomic approach. Can. Entomol., 141, 371396

Hebert, P. D. N., Penton, E. H., Burns, J. M., Janzen, D. H., Hallwachs, W. (2004). Ten species in one: DNA barcoding reveals cryptic species in the neotropical skipper butterfly Astraptes fulgerator. Proced. Natl. Acad. Sci., 101, 14812-14817

Holmberg, E. L. (1884). Viajes al Tandil y a la Tinta, 2nd Parte, Zoologia, Insectos. I. Himenópteros-Hymenoptera [Travels to Tandil and Tinta, 2nd part, Zoology,
Insects. Hymenoptera]. Acta de la Acad. Nac. de Cienc. Córdoba, 5, 117-136

Hurtado-Burillo, M., May-Itzá, W. D. J., Quezada-Eúan, J. J. G., De La Rúa, P., Ruiz, C. (2017), Multilocus species delimitation in Mesoamerican Scaptotrigona stingless bees (Apidae: Meliponini) supports the existence of cryptic species. Sys. Entomol., 42, 171-181

Koch, H. (2010). Combining Morphology and DNA Barcoding Resolves the Taxonomy of Western Malagasy Liotrigona Moure, 1961 (Hymenoptera: Apidae: Meliponini). Afr. Invertbr., 51 (2), 413-421

Kumar, S., Stecher, G., Tamura, K. (2016). MEGA 7: Mol. Evolutionary Genetics Analysis version 7.0 for bigger datasets. Mol. Biol. Evol., 33 (7), 1870-1874.

Lanfear, R., Frandsen, P. B., Wright, A. M., Senfeld, T., Calcott, B. (2016). PartitionFinder 2: new methods for selecting partitioned models of evolution for molecular and morphological phylogenetic analyses. Mol. Biol. Evol., 34 (3), 772-773.

Lepeletier, A. (1841). Histoire Naturelle des Insects. Hyménoptères: Tome Second. [Natural History of the Insects: Second Tome]. Librarie Encyclopédique de Roret, Paris.

Magnacca, K. N., Brown, M. J. (2010). Mitochondrial heteroplasmy and DNA barcoding in Hawaiian Hylaeus (Nesoprosopis) bees (Hymenoptera: Colletidae). BMC Evol. Biol., 10, 174.

Meyer, C. P., Paulay, G. (2005). DNA Barcoding: Error Rates Based on Comprehensive Sampling. PLoS Biol., 3 (12): e422

Michener, C. D. (2007). The bees of the world. Baltimore: The Johns Hopkins University Press.

Miller, M. A., Pfeiffer, W., Schwartz, T. (2010). Creating the CIPRES science gateway for inference of large phylogenetic trees. Proc. Gateway Comput. Environ. Workshop (GCE), 1-8

Moure, J. S. (1941). Apoidea Neotropical, II. Arq. Mus. Parana., 1, 41-99

Moure, J. S., Michener, C. D. (1955). A contribution toward the classification of Neotropical Eucerini (Hymenoptera, Apoidea). Dusenia, 6 (6), 239-331

Moure, J. S., Urban, D., Melo, G. A. R. (2012). Catalogue of Bees (Hymenoptera, Apoidea) in the Neotropical Region. [online] http://www.moure.cria.org.br/catalogue (Accessed on 09 October 2017)

Nei, M., Kumar, S. (2005). Molecular Evolution and Phylogenetics. Oxford University Press, New York.

Nemésio, A., Santos-Júnior, J. E., Santos, F. R. (2013). Eufriesea zhangi sp. n. (Hymenoptera: Apidae: Euglossina), a new orchid bee from Brazil revealed by molecular and morphological characters. Zootaxa, 3609, 568-582

Packer, L., Gibbs, J., Sheffield, C., Hanner, R. (2009). DNA barcoding and the mediocrity of morphology. Mol. Ecol. Resour., 9 (1), 42-50 
Padial, J. M., Miralles, A., De la Riva, I., Vences, M. (2010). The integrative future of taxonomy. Front. Zool., 7, 16.

Pilgrim, E. M., Williams, K. A., Pitts, J. P. (2008). Sex association and synonymy in southwestern U.S. species of Dasymutilla (Hymenoptera: Mutillidae). The Pan-Pac. Entomol., 84 (1), 57-68

Rambaut, A., Suchard, M. A., Xie, D., Drummond, A. J. (2014). Tracer v1.6. [online] http://beast.bio.ed.ac. $\mathrm{uk} /$ Tracer (accessed on 09 October 2017)

Rehan, S. M., Sheffield, C. S. (2011). Morphological and molecular delineation of a new species in the Ceratina dupla species-group (Hymenoptera: Apidae: Xylocopinae) of eastern North America. Zootaxa, 2873, 35-50.

Ronquist, F., Teslenko, M., van der Mark, P., Ayres, D. L., Darling, A., et al. (2012). MrBayes 3.2: Efficient Bayesian Phylogenetic Inference and Model Choice Across a Large Model Space. Sys. Biol, 61 (3), 539542

Sambrook, J., Russel, D. W. (2001). Molecular Cloning: A Laboratory Manual. Cold Spring Harbor Laboratory Press, New York.

Santos Júnior, J. E., Santos, F. R., Silveira, F. A. (2015). Hitting an unintended target: Phylogeography of Bombus brasiliensis Lepeletier, 1836 and the first new Brazilian bumblebee species in a century (Hymenoptera: Apidae). PLoS ONE, 10 (5), e0125847

Schlick-Steiner, B. C., Steiner, F. M., Seifert, B., Stauffer, C., Christian, E., Crozier R. H. (2010). Integrative taxonomy: a multisource approach to exploring Biodiversity. Annu. Rev. Entomol., 55, 421-438

Schrottky, C. (1910). Neue südamerikanische Arten Bienengattung Anthidium Fabr. Wiener Entomolo. Zeits., 29 (7-8), 267-271

Sheffield, C. S., Hebert, P. D. N., Kevan, P. G., Packer, L. (2009). DNA barcoding a regional bee (Hymenoptera: Apoidea) fauna and its potential for ecological studies. Mol. Ecol. Resour., 9, 196-207

Simon, C., Frati, F., Beckenbach, A., Crespi, B., Liu, H., Floors, P. (1994). Evolution, weighting, and phylogenetic utility of mitochondrial gene sequences and a compilation of conserved polymerase chain reaction primers. Ann. Entomol. Soc. Am., 87, 651-701
Smith, F. (1865). Descriptions of some new species of hymenopterous insects belonging to the families Thynnidae, Masaridae and Apidae. Trans. Entomol. Soc. Lond., 2 (3), 389-399

Soldati, L., Kergoat, G. J., Clamens, A. L., Jourdan, H., Jabbour-Zahab, R., Condamine, F. L. (2014). Integrative taxonomy of New Caledonian beetles: species delimitation and definition of the Uloma isoceroides species group (Coleoptera, Tenebrionidae, Ulomini), with the description of four new species. ZooKeys, 415, 133-167

Ståhls, G., Vujic, A., Pérez-Bañon, C., Radenkovic, S., Rojo, S., Petanidou, T. (2009). COI barcodes for identification of Merodon hoverflies (Diptera, Syrphidae) of Lesvos Island, Greece. Mol. Ecol. Resour., 9, 14311438

Stamatakis, A. (2014). RAxML version 8: a tool for phylogenetic analysis and post-analysis of large phylogenies. Bioinformatics, $30(9), 1312-1313$

Urban, D. (1967). As espécies do Gênero Thygater Holmberg, 1884 (Hymenoptera, Apoidae). Zool., 2 (12), 177-309

Urban, D. (1999). Espécies novas de Thygater (Hymenoptera, Apoidea, Antophoridae). Rev. Bras. Zool., 16(1), 213-220

Urban, D., Moure, J. S., Melo, G. A. R. (2012). Eucerini Latreille, 1802. In Moure, J. S., Urban, D., Melo, G. A. R. (Org). Catalogue of Bees (Hymenoptera, Apoidea) in the Neotropical Region. [online] http:/www.moure. cria.org.br/catalogue (Accessed on 09 October 2017)

Wiemers, M., Fiedler, K. (2007). Does the DNA barcoding gap exist? - a case study in blue butterflies (Lepidoptera: Lycaenidae). Front. Zool., 4, 8

Will, K. W., Mishler, B. D., Wheeler, Q. D. (2005). The perils of DNA barcoding and the need for integrative taxonomy. Sys. Biol., 54, 844-851

Williams, P. H., An, J., Brown, M. J. F., Carolan, J. C., Goulson, D., Huang, J., Ito, M. (2012). Cryptic Bumblebee Species: Consequences for Conservation and the Trade in Greenhouse Pollinators. PLoS ONE, 7 (3), e32992

Wolinska, J., Giessler, S., Koerner, H. (2009). Molecular identification and hidden diversity of novel Daphnia parasites from European lakes. Appl. Environ. Microbiol., 75 (22), 7051-7059 